\title{
Development of a real-time PCR method coupled with a selective pre-enrichment step for quantification of Morganella morganii and Morganella psychrotolerans in fish products
}

\author{
Podeur Gaetan ${ }^{1,2,3}$, Dalgaard Paw ${ }^{4}$, Leroi Francoise ${ }^{1}$, Prevost Hervé ${ }^{2,3}$, Emborg Jette ${ }^{4}$, Martinussen \\ Jan $^{5}$, Hansen Lars Hestbjerg ${ }^{6}$, Pilet Marie France ${ }^{2,3,}$
}

${ }^{1}$ Ifremer, Laboratory of Microbial Ecosystem and Marine Molecules for Biotechnology, Nantes, France

${ }^{2}$ LUNAM Université, Oniris, UMR1014, Secalim, Nantes, France

${ }^{3}$ INRA, Nantes, France

${ }^{4}$ National Food Institute (DTU Food), Technical University of Denmark, Kgs. Lyngby, Denmark

${ }^{5}$ DTU System Biology, Technical University of Denmark, Kgs. Lyngby, Denmark

${ }^{6}$ Department of Environmental Science, Aarhus University, Roskilde, Denmark

${ }^{*}$ Corresponding author : Marie-France Pilet, tel.: + 33240687811 ;

email address : marie-france.pilet@oniris-nantes.fr

\begin{abstract}
:
Histamine fish poisoning is common and due to toxic concentrations of histamine often produced by Gram-negative bacteria in fin-fish products with a high content of the free amino acid histidine. The genus Morganella includes two species previously reported to cause incidents of histamine fish poisoning. Morganella morganii and Morganella psychrotolerans are both strong producer of histamine. However, little is known about the occurrence and critical stages for fish contamination with these bacteria. To elucidate contamination routes of Morganella, specific real-time quantitative PCR (RTi qPCR) methods for quantification of $M$. morganii and $M$. psychrotolerans have been developed. Selective primers amplified a $110 \mathrm{bp}$ region of the vasD gene for $M$. psychrotolerans and a $171 \mathrm{bp}$ region of the galactokinase gene for $M$. morganii. These primer-sets showed high specificity as demonstrated by using purified DNA from 23 other histamine producing bacteria and 26 isolates with no or limited histamine production. The efficiency of the qPCR reactions on artificially contaminated fish samples were $100.8 \%$ and $96.3 \%$ respectively. The limit of quantification (LOQ) without enrichment was $4 \log$ CFU/g. A quantitative enrichment step with a selective medium was included and improved the sensitivity of the methods to a LOQ of below $50 \mathrm{CFU} / \mathrm{g}$ in seafood. RTi qPCR with or without enrichment were evaluated for enumeration of Morganella species in naturally contaminated fresh fish and lightly preserved seafood from Denmark. These new methods will contribute to a better understanding of the occurrence and histamine production by Morganella species in fish products, information that is essential to reduce the unacceptably high frequency of histamine fish poisoning.
\end{abstract}




\section{Highlights}

- Quantification of Morganella species in fish products by RTi qPCR $\rightarrow$ Sensitivity of the assay was improved with a quantitative selective enrichment step to $50 \mathrm{CFU} / \mathrm{g}$ The assays accurately quantified Morganella in fresh and lightly preserved fish Development of a specific tool to quantify main histamine producing bacteria in fish

Keywords : histamine-producing bacteria, tuna, selective medium, Enterobacteriaceae, galactokinase, typeVI secretion system 


\section{Introduction}

Histamine fish poisoning (HFP) is common worldwide and due to consumption of a range of dark-fleshed fin-fishes (Dalgaard et al., 2008). Between 2008-2010, HFP was responsible for $51 \%$ of all seafood related outbreaks of disease in France and in Europe and for $20 \%$ in United States (CDC, 2011; Helwigh et al., 2012; InVS, 2011). HFP is typically caused by consumption of fish muscle containing high concentration of histamine (> $500 \mathrm{mg} / \mathrm{kg}$ ) which can be observed in fish species with high level of histidine such as Scombridae (tuna, mackerel...), Clupeidae (herring, sardine...) and other species like Coryphaena hippurus (mahi-mahi) or Belone belone (garfish) (Hungerford, 2010). HFP is a relatively mild illness with allergy-like symptoms that appear some minutes to few hours after consumption of the food. They are mainly characterized by rash, diarrhea, nausea, headache, flushing and sweating (Prester, 2011).

Histamine in fish flesh is produced by decarboxylation of free histidine by bacterial decarboxylase. Gram-negative marine and enteric bacteria have been identified as the main bacterial groups responsible for HFP in fish products (Bjornsdottir et al., 2009; Dalgaard et al., 2008; Veciana-Noguès et al., 2004). Histamine producing bacteria (HPB) can be subdivided into low and high producers of histamine based on the formation of histamine in a broth culture medium containing histidine. The high histamine producers include mesophilic species such as M. morganii, Enterobacter aerogenes, Hafnia alvei, Raoultella planticola and Photobacterium damselae, which are able to produce more than $1000 \mathrm{mg} / \mathrm{l}$ of histamine in tryptone soy broth supplemented with $2 \%$ histidine after $24-48 \mathrm{~h}$ incubation at temperatures above $15^{\circ} \mathrm{C}$ (Bjornsdottir et al., 2009). High histamine-producing and psychrotolerant bacteria have also been described, including Photobacterium phosphoreum (Kanki et al., 2004) and M. psychrotolerans (Emborg et al., 2006). Both species produce histamine at low temperature until $0^{\circ} \mathrm{C}$ in fish products (Dalgaard et al., 2006; Emborg et al., 2005). 
Whereas all Morganella isolates seem to be strong histamine producers, intra-species variability exists for other species including P. phosphoreum (Dalgaard et al., 2006; Emborg et al. 2005; Kim et al., 2002; Klausen et al., 1987). Both M. morganii and M. psychrotolerans have been isolated from fish products (fresh tuna, tuna in sauce, cold-smoked tuna) responsible for outbreaks (for a review, see Dalgaard et al., 2008). Despites those facts, there is a lack of data on prevalence of Morganella spp. in fish products, probably due to the absence of sufficiently sensitive and specific enumeration method. Previous experiments of detection of HPB have been performed on differential media (Mavromatis and Quantick, 2002; Tao et al., 2009) based on color modification of $\mathrm{pH}$ indicators once histidine is converted to histamine during bacterial growth. However, these methods are time consuming and unreliable (Bjornsdottir et al., 2009). Nowadays, molecular methods based on RTi qPCR are more reliable for detection, identification and quantification of bacteria but their lack of sensitivity when used with food products remains a problem (Postollec et al., 2011). Bjornsdottir-Butler et al. (2011a) developed a RTi qPCR method based on the primers of Takahashi et al. (2003) designed on the histidine decarboxylase gene to quantify Gramnegative and high HPB. That method has been set-up for mesophilic species but cannot detect P. phosphoreum or M. psychrotolerans (experiments in our laboratory, data not shown). More recently, RTi qPCR methods for quantification of M. morganii (Ferrario et al., 2012a, 2012b) and viable $P$. phoshoreum (Macé et al., 2013) in fish products have been proposed. However, in those studies the detection limit of RTi qPCR was typically between 3-4 log CFU/g in food products. This limit is too high to study the occurrence of Morganella spp. in fish products in which expected contamination level is most likely less than $100 \mathrm{CFU} / \mathrm{g}$. To overcome this problem of the sensitivity of RTi qPCR methods, enrichment steps with selective media have been proposed, allowing quantification of 1-10 CFU/g for e.g. the pathogenic bacteria Listeria 
monocytogenes (O’ Grady et al., 2008) and Salmonella (McGuinness et al., 2009) in different food products.

The objectives of the present study were to develop two specific and sensitive RTi qPCR methods for quantification of $M$. morganii and $M$. psychrotolerans in fish products. Selective primers for both species have been designed and evaluated against isolates of HPB and nonHBP isolates. These RTi qPCR methods used in combination with a new enrichment step reduced the LOQ and increase the methods field of application for fish products.

\section{Materials \& methods}

\subsection{Bacterial strains and pre-culturing}

Bacterial strains used in this study are listed in Table 1. Strains were grown in Brain Heart Infusion (BHI, Biokar Diagnostics, Beauvais, France) at $20^{\circ} \mathrm{C}$ during $24 \mathrm{~h}$, for Morganella strains, and during 24-48 h for other strains, except for $P$. phosphoreum which was cultivated at $15^{\circ} \mathrm{C}$ in $\mathrm{BHI}$ with $2 \% \mathrm{NaCl}$. The strains were stored at $-80^{\circ} \mathrm{C}$ in their culture medium with $10 \%$ glycerol.

\subsection{DNA extraction}

For bacterial cultures, DNA extraction was performed on $1.5 \mathrm{ml}$ cultures that have reached a concentration of at least $8 \log \mathrm{CFU} / \mathrm{ml}$. After centrifugation during $10 \mathrm{~min}$ at $8500 \mathrm{x} \mathrm{g}$, the chromosomal DNA of all bacterial isolates was extracted using the Qiagen DNeasy Blood and Tissue Kit (Qiagen, S.A., Courtaboeuf, France).

The DNA extraction on fish tissue was adapted from a protocol developed for raw salmon to quantify P. phosphoreum by RTi qPCR (Macé et al., 2013). Briefly, $30 \mathrm{~g}$ portion of seafood samples (tuna, mackerel or herring) was aseptically weighed in a sterile stomacher bag and 5fold diluted with sterile peptone-salt water $(0.1 \%$ peptone, $0.85 \%$ salt $)$. Ten milliliters of 
homogenized suspension were filtered on a Nucleospin Filter L (Macherey-Nagel, Hoerdt, France). The following extraction of DNA was performed as described by Macé et al. (2013). DNA was purified using the DNeasy Blood \& Tissue Kit as described in the Qiagen instruction manual.

\subsection{Genomics data and primer design}

Shotgun sequencing was performed in Denmark using Roche FLX 454 pyrosequencing on DNA from the $M$. morganii strain U6/1 and on DNA from the type strain of $M$. psychrotolerans $\mathrm{U} 2 / 3^{\mathrm{T}}=\mathrm{LMG} 23374^{\mathrm{T}}=\mathrm{DSM} 17886^{\mathrm{T}}$ (Emborg et al., 2006; Meyer et al., 2008). Sequencing was done using the FLX Titanium sequencing kit and 1 region of an XLR70 pico titre plate per strain. Contigs for each strain were assembled using the Newbler assembler software version 2.0.01.14 provided with the GS FLX instrument and annotated by using the RAST annotation server (Aziz et al., 2008). Genome sequencing and assembly of the M. morganii $\mathrm{U} 6 / 1$ and M. psychrotolerans $\mathrm{U} 2 / 3^{\mathrm{T}}$ resulted in 51 and $28 \mathrm{x}$ coverage on 3,9 $\mathrm{Mb}$ and 4,2 Mb size genomes, respectively. Genomes were assembled into 123 (M. morganii $\mathrm{U} 6 / 1$ ) and 292 (M. psychrotolerans $\mathrm{U} 2 / 3^{\mathrm{T}}$ ) large contigs (>500 bp).

Thirty primers pairs were designed for M. psychrotolerans and M. morganii using the Geneious Software (Geneious version 6.1, Biomatters Ltd.) based on the Primer3 calculation method (Untergasser et al., 2007) and the Primer-Blast software (NCBI, UK). Primers pairs were initially evaluated in silico by using the nucleotide Blast program to check their specificity for M. morganii or M. psychrotolerans against all genomic data of GenBank (NCBI, UK) and tested in vitro as described in 2.4 using appropriate hybridization temperatures. The selected primers VasD-F4 (5'-AAATCGCCATCACACTCCTTG-3') and VasD-R4 (5'-TTCAAAACGGGAGTCCTCACTG-3') were designed on the vasD gene from the Type VI secretion system of $M$. psychrotolerans. This primer set matched respectively 
position 146-166 and 234-255 of the M. psychrotolerans $\mathrm{U} 2 / 3^{\mathrm{T}}$ vasD gene (Genbank accession number KP069481). For M. morganii, the primers GalK-F4 (5'ACAGTGCTTCGGCGCATCCC-3') and GalK-R4 (5'-GCAGCCACCACGCAGACCTT-3') were obtained on the galactokinase gene $(\mathrm{galK})$ and matched respectively position $39-58$ and 190-209 of the galactokinase gene of M. morganii U6/1 (Genbank accession number KP069480).

\subsection{Real-time PCR amplification}

Inclusivity and exclusivity of primers (TAG Copenhagen, Denmark or Invitrogen, Illkirch, France) designed for M. morganii and M. psychrotolerans were tested on bacterial DNA extracted from the strains listed in Table 1. Genomic DNA was measured using a Nanovalue (Applied Biosystem, Saint-Aubin, France) and diluted to $4 \mathrm{ng} / \mu \mathrm{l}$. Specificity of the RTi qPCR assay was tested using 4 ng of DNA.

Real-time qPCR was conducted in a $15 \mu 1$ reaction volume using the following reaction mixture: 1 U of Iq SYBR ${ }^{\circledR}$ Green Supermix (Biorad, Hercules, US), $300 \mathrm{nM}$ of each VasD or GalK forward and reverse primers, nuclease free $\mathrm{H}_{2} \mathrm{O}$ and $1 \mu 1$ of DNA template. Real-time PCR cycling was performed using a CFX-96 instrument (Biorad, Marnes-la-Coquette, France) or a Mx3000P thermocycler (Stratagene, AH Dianostics, Aarhus, Denmark). The cycling parameters were: $95^{\circ} \mathrm{C}$ hold for $180 \mathrm{~s}$ for initial denaturation and activation of the hotstart polymerase, followed by 40 cycles of amplification of $95^{\circ} \mathrm{C}$ for $15 \mathrm{~s}, 60^{\circ} \mathrm{C}$ for $30 \mathrm{~s}$ for M. morganii, or $62^{\circ} \mathrm{C}$ for $30 \mathrm{~s}$ for M. psychrotolerans. Fluorescence was read at the end of each amplification cycle. At the end of the 40 cycles, a melting curve was conducted between $55^{\circ} \mathrm{C}$ and $95^{\circ} \mathrm{C}$ with a $0.5^{\circ} \mathrm{C} / 5 \mathrm{~s}$ increment read. The cycle threshold $\left(\mathrm{C}_{\mathrm{T}}\right)$ value was determined using a background limit of 0.02 . 
To obtain standard curves relating $\mathrm{C}_{\mathrm{T}}$-values and cell concentrations (log CFU/g), ten-fold serially dilutions of a culture of the type strains $M$. psychrotolerans $\mathrm{U} 2 / 3^{\mathrm{T}}$ and $M$. morganii LMG7874 ${ }^{\mathrm{T}}=\mathrm{CIP} A 231^{\mathrm{T}}$ (Table 1) were inoculated on pieces of canned tuna flesh. DNA extraction was performed on each piece of tuna inoculated with decreasing known concentrations of each strain between 2 to $8 \log$ CFU/g. Specific RTi qPCR was performed as described above and enumeration of each strain was made on BHI agar incubated $24 \mathrm{~h}$ at $20^{\circ} \mathrm{C}$.

For quantification in naturally contaminated products a positive control was made with DNA extracted as described in section 2.2 from $30 \mathrm{~g}$ of fish inoculated with $M$. morganii LMG $7874^{\mathrm{T}}$ or M. psychrotolerans $\mathrm{U} 2 / 3^{\mathrm{T}}(9 \log \mathrm{CFU} / \mathrm{g})$. Negative controls consisted in DNA extracted from canned tuna and sterile water.

\section{Development of a Morganella enrichment (MoE) medium}

To improve sensitivity of the RTi qPCR methods, enrichment steps were added. A selective enrichment medium was developed to allow optimal growth of Morganella species and to inhibit most of the other HPB. High histamine-producer M. psychrotolerans U2/3 ${ }^{\mathrm{T}}$, F39-1, JB-T11, M. morganii LMG7874 ${ }^{\mathrm{T}}$, DSM14850 ${ }^{\mathrm{T}}, 03 \mathrm{~A} 11$, R. planticola DSM3069 ${ }^{\mathrm{T}}$, E. aerogenes LMG2094 ${ }^{\mathrm{T}}$, K. oxytoca $\mathrm{LMG} 3055^{\mathrm{T}}$ and H. alvei DSM30163 ${ }^{\mathrm{T}}$ (Table 1) were selected to test the effect of 15 antibiotics and of the 2-deoxy-D-galactose substrate. This substrate was tested as the hexose analog can be lethal for microorganisms able to metabolize galactose (Alper and Ames, 1975). Tests were performed in honeycomb 2 microplates with 100 wells (Thermo Electron Oy, Vantaa, Finland), each well being filled with $300 \mu 1$ of Nutrient Broth (NB, CM0001, Oxoid, Basingstoke, UK) with or without different concentrations of antibiotic (Table 2) or with 2-deoxy-D-galactose. NB was supplemented with $0.2 \mathrm{mg} / \mathrm{ml}$ of 2-deoxy-D-galactose and incubated with or without an overlay of sterile 
paraffin oil. Wells were inoculated with an overnight pre-culture of each strain at $25^{\circ} \mathrm{C}$ in $\mathrm{NB}$, at a final concentration of $10^{2} \mathrm{CFU} / \mathrm{ml}$. A negative control was performed using noninoculated NB broth. Growth was followed during $72 \mathrm{~h}$ at $25^{\circ} \mathrm{C}$ by absorbance measurement at $540 \mathrm{~nm}$ and with measurements every 20 minutes (Bioscreen C, Labsystem, Helsinki, Finland). Plates were shaked $10 \mathrm{~s}$ at medium speed before each measurement. Experiments were done in duplicate and growth data were analyzed by Excel (Microsoft Corporation, Redmond, US) to determine the growth inhibiting effect of the studied antimicrobials.

The final MoE medium was adapted from Emborg and Dalgaard (2008) and consisted of buffered Lucia-Bertani broth added L-histidine and colistin: $10.0 \mathrm{~g} / \mathrm{l}$ bacto tryptone (211705, Becton and Dickinson Company, Sparks, MD, USA), 5.0 g/l yeast extract (212750, BD), 7.0 g/l $\mathrm{KH}_{2} \mathrm{PO}_{4}$ (1.04873, Merck, Darmstadt, Germany), 7.0 g/l K ${ }_{2} \mathrm{HPO}_{4}$ (1.05104, Merck) and $10.0 \mathrm{~g} / \mathrm{l}$ L-histidine monohydrochloride monogydrate (Sigma, H8125). The autoclaved $\left(121^{\circ} \mathrm{C}, 15 \mathrm{~min}\right)$ and chilled medium was added a filter sterilized solution of colistin-sulfate salt (Sigma, C4461) to a final concentration of $32 \mathrm{mg} / \mathrm{l}$. pH was adjusted to 6.50 .

\subsection{Development of a quantitative enrichment procedure}

To calculate the concentration of $M$. psychrotolerans or M. morganii in fish product from concentrations determined by RTi qPCR after enrichment in MoE, the maximum specific growth rate $\left(\mu_{\max }\right)$ of each Morganella species in the MoE medium were determined. Precultures (NB, $25^{\circ} \mathrm{C}, 12 \mathrm{~h}$ ) of, respectively, four M. psychrotolerans strains (MIX-Mp: U2/3 ${ }^{\mathrm{T}}$, JB-T11, JB-T12, U2/5) or four M. morganii strains (MIX-Mm: 25a32, AP28, LMG7874 ${ }^{\mathrm{T}}$, DSM14850 ${ }^{\mathrm{T}}$ ) were mixed. Appropriate dilutions were inoculated in peptone-salt water, canned tuna and cooked shrimp to obtain a concentration of $250 \mathrm{CFU} / \mathrm{ml}$ or $250 \mathrm{CFU} / \mathrm{g}$. Thirty grams of inoculated seafood were five-fold diluted with peptone-salt water and homogenized in a stomacher 400 (Seward Medical, London, UK). $1.00 \mathrm{ml}$ of the homogenate 
was then transferred to $9.00 \mathrm{ml}$ of MoE medium and growth was determined in duplicate by viable counting during storage at $10^{\circ} \mathrm{C}$ for $M$. psychrotolerans and at $37^{\circ} \mathrm{C}$ for $M$. morganii. These temperatures for specific incubation were selected for the two species based on the known effect of temperature on the growth rate of $M$. psychrotolerans and $M$. morganii (Emborg and Dalgaard, 2008). In the same way, the peptone-salt water solution with 250 CFU/ml was five-fold diluted and then $1 \mathrm{ml}$ was inoculated in the MoE medium. Samples were removed for bacterial enumeration and DNA extraction after 0, 14, 24, 38, 49, 63 and 86 $\mathrm{h}$ for $M$. psychrotolerans and after 0, 1, 3, 4, 6, 7 and $9 \mathrm{~h}$ for $M$. morganii. Enumeration of Morganella was done on Tryptone Soya Agar (TSA, CMO131, Oxoid) at $25^{\circ} \mathrm{C}$ after $36 \mathrm{~h}$ of incubation. DNA extraction was done with $1 \mathrm{ml}$ of MoE as described above (See 2.2). For each food matrix, the maximum specific growth rate $\left(\mu_{\max }\right)$ of $M$. psychrotolerans and $M$. morganii in MoE was determined by fitting growth data using an exponential model (Eq. 1).

$\log \left(N_{t}\right)=\log \left(N_{0}\right)+\left(\mu_{\max } \times \mathrm{t}\right) / \operatorname{Ln}(10)$

where $N_{0}$ and $N_{t}$ are cell concentrations $(\mathrm{CFU} / \mathrm{ml})$ at time zero and at time $t$, respectively.

\subsection{Quantification of Morganella species in natural contaminated fish products by RTi $\underline{q P C R}$}

The RTi qPCR methods were used to quantify M. psychrotolerans and M. morganii on different fish products from Denmark (Table 3). Tuna loins from the local fish market and herring provided by local fisherman were transported to the laboratory and kept overnight in ice before being processed and analysed. Tuna loins were cut in 8 pieces of $60 \mathrm{~g}$ and then vacuum packed. Herrings were eviscerated, tail and head were removed and filets were vacuum packed using a packaging film with low gas permeability. Frozen tuna steaks, hot smoked mackerel, cold-smoked herring and Matjes herring fillets bought in supermarket were already vacuum- or modified atmosphere packed. The fresh products were then stored for one 
week at $2^{\circ} \mathrm{C}$ whereas previously frozen tuna and lightly preserved products were kept at $10^{\circ} \mathrm{C}$. The products were analyzed in triplicate ( 3 packs) on the day of processing and after one week of storage. Thirty grams of product were 5-fold diluted with chilled peptone-salt water, homogenized with stomacher whereafter RTi qPCR was performed directly as described in 2.4. In addition, for each pack, two times $1.00 \mathrm{ml}$ of the homogenized solution was added to two times $9.00 \mathrm{ml}$ of MoE medium (two tubes) and then incubated respectively during $72 \mathrm{~h}$ at $10^{\circ} \mathrm{C}$ or $7 \mathrm{~h}$ at $37^{\circ} \mathrm{C}$ before DNA extraction and quantification by the RTi qPCR assay (see 2.4). Total viable counts were determined at each time of analysis on spread plates of Long \& Hammer agar $(\mathrm{L} \& \mathrm{H})$ incubated 5 days at $15^{\circ} \mathrm{C}$ (NMKL, 2006; Van Spreekens, 1974). Plates were also observed in the dark to enumerate luminous $P$. phosphoreum colonies. Enterobacteriaceae were enumerated using Tryptone Soya Agar/Violet Red Bile Glucose (TSA/VRBG) agar as previously described (Emborg and Dalgaard, 2008). 24 colonies from the TSA/VRBG agar were isolated and identified by using simple biochemical tests (Dalgaard et al. 2006).

\section{3- Results}

\subsection{Specificity of the real-time PCR assay}

A set of 30 primers pairs has been designed and tested on M. pyschrotolerans and $M$. morganii strains. Of these primers, only the VasD-FR4 and the GalK-FR4 primers were specific for M. psychrotolerans and M. morganii, respectively. Establishment of the specificity of the VasD and GalK primers were tested in silico by sequence alignment using the GenBank database and by RTi qPCR on 13 M. psychrotolerans, 11 M. morganii and 49 HPB or non-HPB isolates (Table 1). The GalK-FR4 primers presented a 100\% homology sequence with the M. morganii related gene available in the GenBank database (MU9_2965).

For the VasD-FR4 primers, partial sequence alignments were obtained with 14 non- 
Enterobacteriaceae vasD sequences. In vitro RTi qPCR tests indicated a good specificity of the primers for the $13 \mathrm{M}$. psychrotolerans and the $11 \mathrm{M}$. morganii isolates. The mean $\mathrm{C}_{\mathrm{T}}$ values were $16.8 \pm 0.3(\mathrm{n}=13)$ and $15.2 \pm 0.5(\mathrm{n}=11)$ with $4 \mathrm{ng}$ of DNA extracted from broth cultures of M. psychrotolerans and M. morganii, respectively. RTi qPCR exclusivity test on $49 \mathrm{HPB}$ or non-HPB isolates resulted in $\mathrm{C}_{\mathrm{T}}$ values higher than 29 . That was considered as the $\mathrm{C}_{\mathrm{T}}$ threshold for specific detection of Morganella species obtained on pure cultures in liquid medium. This threshold was increased to $31 \mathrm{C}_{\mathrm{T}}$ when bacterial DNA was extracted from fish samples (tuna) (data not shown). The melting temperature calculated at the end of each real-time PCR assay was $83.5^{\circ} \mathrm{C}$ for M. psychrotolerans and $86^{\circ} \mathrm{C}$ for M. morganii.

\subsection{Efficiency and detection range of the RTi qPCR assay}

The standard curve showed a linear relation between cell concentrations $(\log \mathrm{CFU} / \mathrm{g})$ and $\mathrm{C}_{\mathrm{T}}$ values for type strains of both Morganella species in canned tuna (Fig. 1). No signal was detected by RTi qPCR for the negative control. The linear relation was determined on a 5 log (CFU/g) range from ca. 3 to ca. 8 log CFU/g for both species (Fig. 1). The linear relations was $\mathrm{C}_{\mathrm{T}}=-3.30 \mathrm{x}$ viable count $(\log \mathrm{CFU} / \mathrm{g})+41.60\left(\mathrm{R}^{2}=0.99\right)$ for $M$. psychrotolerans, with an efficiency of $100.8 \%$ on inoculated fish. For M. morganii the standard curve was $\mathrm{C}_{\mathrm{T}}=-3.413$ $\mathrm{x}$ viable count $(\log \mathrm{CFU} / \mathrm{g})+44.16\left(\mathrm{R}^{2}=0.99\right)$ with an efficiency of $96.3 \%$ (Fig. 1).

Concentrations of Morganella lower than $4 \log (\mathrm{CFU} / \mathrm{g})$ resulted in $\mathrm{C}_{\mathrm{T}}$ values higher than 31 and therefore could not be distinguished from non-specific reactions with other HPB or nonHPB. For that reason, the lower and upper LOQ of each Morganella species in fish products using the RTi qPCR method have been set to 4 and 8 log CFU/g respectively.

\subsection{Development of an enrichment medium}

The substrate 2-deoxy-D-Galactose showed an inhibition of M. psychrotolerans growth and was not further studied. Most antibiotics, in the concentrations tested, inhibited growth of 
Morganella strains and had a species specific inhibitory effect on non-Morganella HPB

(Table 2). In contrast, colistin inhibited the growth of all non-Morganella HPB and concentrations up to $32 \mathrm{mg} / \mathrm{l}$ did not inhibit growth the Morganella isolates (Table 2).

\subsection{RTi qPCR quantification using an enrichment step}

Three matrixes (peptone-salt water, canned tuna and cooked shrimp) have been used to study the subsequent growth kinetics of Morganella strains in MoE. The $\mu_{\max }$-values of $M$.

psychrotolerans in MoE at $10^{\circ} \mathrm{C}$ were $0.182 \mathrm{~h}^{-1}$ for MIX-Mp inoculated from peptone-salt water, $0.180 \mathrm{~h}^{-1}$ from canned tuna and $0.180 \mathrm{~h}^{-1}$ from cooked shrimp (Fig. 2). Statistical analysis showed no significant difference between growth rates obtained on the three matrixes ( $p>0.05$ ), thus growth rate of M. psychrotolerans has been set to $0.180 \mathrm{~h}^{-1}$ in fish products. The $\mu_{\text {max }}$-values of MIX-Mm at $37^{\circ} \mathrm{C}$ were $1.939 \mathrm{~h}^{-1}$ from peptone-salt water, $2.002 \mathrm{~h}^{-1}$ from canned tuna, and $2.130 \mathrm{~h}^{-1}$ from cooked shrimp. Again, values were not significantly different and growth rate for M. morganii has been set at $2.024 \mathrm{~h}^{-1}$.

To complete the enrichment method, standard curves to determine the relation between $\mathrm{C}_{\mathrm{T}}$ obtained by RTi qPCR and cell concentrations (log CFU/g) obtained by classical plate count were performed for each species when growing in the MoE medium. The linear relation determined for both species was scaled from $4.0 \pm 0.5$ to $8.0 \pm 0.5 \log$ CFU/ml. For $M$. morganii, the equation was $\mathrm{C}_{\mathrm{T}}=-3.378 \mathrm{x}$ viable count $(\log \mathrm{CFU} / \mathrm{ml})+44.95\left(\mathrm{R}^{2}=0.99\right)$ with an efficiency of $97.71 \%$. For $M$. psychrotolerans, the equation was $\mathrm{C}_{\mathrm{T}}=-3.464 \mathrm{x}$ viable count $(\log \mathrm{CFU} / \mathrm{ml})+47.69\left(\mathrm{R}^{2}=0.99\right)$ with an efficiency of $94.54 \%$ (Fig. 3).

After enrichment, the initial cell concentration in fish is calculated from the concentration obtained by RTi qPCR in the MoE medium and by taking into account the $\mu_{\max }$-value of $M$. psychrotolerans or M. morganii, the time of enrichment and the dilution of the fish sample (Eq. 2): 


$$
I C=C a E-\left(\left(\mu_{\max } x E T\right) / \ln 10\right)+\log (D F)
$$

where $I C$ is the initial cell concentration in the fish product (log CFU/g), $C a E$ the concentration in MoE medium after enrichment as determined by RTi qPCR (log CFU/ml), $E T$ the enrichment time (h) and $D F$ the total dilution factor resulting from homogenization and transfer of the homogenate to the MoE medium.

\subsection{Quantification of Morganella in fish products by RTi qPCR}

Just after processing of the studied seafoods, the viable counts on L\&H were under $4.2 \mathrm{log}$ CFU/g for fresh fish and under $1.9 \mathrm{log}$ CFU/g for lightly preserved products (Table 3). After storage during one week this concentration increased up to $7 \log \mathrm{CFU} / \mathrm{g}$ in herring fillets and hot smoked mackerel. Most colonies on L\&H agar plates were bioluminescent and the microbiota therefore seemed to be dominated by $P$. phosphoreum. Viable counts of the four others fish product remained under $4.3 \mathrm{log}$ CFU/g. Enterobacteriaceae were not detected after processing and remained under $2.6 \log$ CFU/g after one week (Table 3).

RTi qPCR enumeration with or without the enrichment step did not allow to detect the presence of $M$. psychrotolerans or M. morganii in the studied fish samples. To confirm these results the MoE medium was plated on TSA/VRBG agar. No Enterobacteriaceae was detected in MoE after $7 \mathrm{~h}$ enrichment at $37^{\circ} \mathrm{C}$, confirming the absence of $M$. morganii in the fish samples. Enumeration on TSA/VRBG plates after $72 \mathrm{~h}$ of enrichment at $10^{\circ} \mathrm{C}$, for tuna loins, herring fillets and hot smoked mackerel showed bacterial growth up to $8 \log \mathrm{CFU} / \mathrm{ml}$.. However, these bacteria on TSA/VRBG agar plates were Pseudomonas/Shewanella-like and not Morganella/Enterobacteriaceae. These results support those obtained by RTi qPCR on MoE medium with $\mathrm{C}_{\mathrm{T}}$-values higher than 30 and corresponding to concentrations of $M$. psychrotolerans below $5.1 \log \mathrm{CFU} / \mathrm{ml}$ in the MoE medium and below $1.2 \log \mathrm{CFU} / \mathrm{g}$ in 
herring fillets and hot smoked mackerel after storage for one week at respectively, $2^{\circ} \mathrm{C}$ or $10^{\circ} \mathrm{C}$

\section{Discussion}

After 2009, RTi qPCR methods have been developed for HPB detection and quantification in seafood. These methods have focused on mesophilic HPB species and have not been tested for M. psychrotolerans and P. phosphoreum (Bjornsdottir-Butler et al., 2011a, 2011b; Ferrario et al., 2012a, 2012b). RTi qPCR methods have previously been used in combination with an enrichment step to qualitatively detect pathogenic bacteria including Listeria monocytogenes (O'Grady et al., 2008; O'Grady et al., 2009) and Escherichia coli (Chern et al., 2011; Taskin et al., 2011) in food products. Spoilage bacteria responsible for sensory defect have also been quantified by RTi qPCR, e.g. Brochotrix thermosphacta (Mamlouk et al., 2012) and P. phosphoreum (Macé et al., 2013).

The present study focused on quantification of Morganella species in fish products as these are strongly histamine producing bacteria and have been responsible for HFP outbreaks. Specific and sensitive quantification methods were missing to study their occurrence and to help management of histamine formation in seafood. Available methods are limited in specificity or in sensitivity to obtain reliable results to improve our knowledge on these HPB. Recently, a RTi qPCR method was developed for quantification of $M$. morganii by Ferrario et al.(2012a), but this method was not tested for selectivity in relation to M. psychrotolerans although the type strain $\left(\mathrm{U} 2 / 3^{\mathrm{T}}\right)$ has been available in culture collections since 2007 (Emborg et al., 2006). Primers from Ferrario et al.(2012b) were checked in silico in the present study and might lead to unspecific reaction with $M$. psychorotolerans. To obtain a specific quantification method for each Morganella species primers for M. psychrotolerans have been designed on the vas $D$ gene as part of the Type VI secretion system, recently discovered in 
Vibrio cholera by Filloux et al. (2008). In the M. psychrotolerans genome, the type VI secretion system is composed of 17 genes which are missing on the $M$. morganii genome and this allowed the developed RTi qPCR method to specifically detect the Morganella psychrotolerans . For M. morganii, the choice of primer cites were the galactokinase gene due to absence of this gene in M. psychrotolerans, unable to ferment D-galactose (Emborg et al., 2006). These two pairs of primers were $100 \%$ inclusive for their target species. Without enrichment the developed RTi qPCR methods can be used for specific detection and quantification of Morganella species in samples with high concentrations of these bacteria, for example fish products responsible of HFP. This is the first method develop for quantification of $M$. psychrotolerans and it seems useful to increase our understanding of the relative importance of psychrotolerant and mesophilic bacteria responsible for histamine formation e.g. in relation to outbreaks of HFP.

Using a specific enrichment medium, the developed RTi qPCR methods may be sufficiently sensitive to enumerate Morganella species in newly processed seafood and within the seafood processing environment. Colistin allowed growth of Morganella and reduced growth of some of the other well known and strongly histamine producing Enterobacteriaceae during enrichment (Table 2). Furthermore, data for fresh herring and hot smoked mackerel indicated that enrichment in $\mathrm{MoE}$ without $\mathrm{NaCl}$ limited growth of $P$. phosphoreum and thereby the potential interference from this marine bacterium that often are present in high concentration in fresh and lightly preserved seafood (Dalgaard et al., 1997). Nevertheless, selectivity of the MoE medium in relation to other microorganisms that may influence growth of the Morganella species during enrichment deserves further study.

Enrichment at $37^{\circ} \mathrm{C}$ for $M$. morganii allowed DNA extraction and quantification within one working day. In contrast, for M. psychrotolerans, incubation at $10^{\circ} \mathrm{C}$ was chosen to reduce the growth of M. morganii in the MoE medium. Clearly, the suggested enrichment and RTi qPCR 
method for M. psychrotolerans is not a rapid method. However, it is the only method available for specific enumeration $M$. psychrotolerans and with a LOQ below $50 \mathrm{CFU} / \mathrm{g}$ in fish products. This method seems valuable to obtain information about the occurrence and growth of this strongly histamine producing bacteria that has been responsible for outbreaks of HFP. M. psychrotolerans has been isolated sporadically in seafood worldwide (Emborg et al., 2006; Macé et al., 2012; Torodo et al., 2014). Available information on its occurrence is far from sufficient to quantitatively evaluate its contribution to the risk of histamine formation and HFP. The enrichment and RTi qPCR method suggested in the present study has the potential to overcome this problem.

Lag phases of the Morganella species during growth in the MoE have not been studied. For enrichment from fresh or lightly preserved seafood lag phases are likely to be of little practical importance. However, for frozen seafood and more preserved, like salted and/or dried, products significant lag times may be observed during enrichment in MoE. Using eq. 2 to calculate cell concentration in fish products will result in underestimation of cell concentrations when lag times in the MoE medium are observed and this aspect needs further study for the suggest enrichment procedures at $10^{\circ} \mathrm{C}$ or $37^{\circ} \mathrm{C}$. Enrichment steps have previously been proposed to lower the detection limit of RTi qPCR methods (O'Grady et al., 2009, Taskin et al., 2011). However in those studies, the enrichment step did not allow quantification of the initial concentration of the bacteria detected. In the present study, the determination of the growth rate in the enrichment media made it possible to calculate the initial concentration from different enrichment times using Eq. (2). This approach resembles quantitative incubation methods that are known for their ability to enumerate low concentrations of bacteria as shown e.g. for P. phosphoreum in fish samples (Dalgaard et al., 1996). 
The LOQ for the developed RTi qPCR methods was limited by the 50-fold dilution during homogenization (x5) and inoculation of the MoE medium (x10). A direct enrichment with 30 $\mathrm{g}$ of fish flesh homogenized in $120 \mathrm{ml}$ of MoE medium may lower the LOQ but need further study to evaluate if the growth rate during enrichment will depend on the type of seafood e.g. for fish products with different $\mathrm{pH}$ and salt content. Otherwise, a filtration method has already shown good results on pathogenic bacteria and might be tested to increase sensitivity to 1 CFU/g of products (Murakami, 2012).

The methods developed in this study for quantification of M. psychrotolerans or M. morganii in fish products may be used to survey occurrence of these important HPB in fish products and to improve management of histamine formation.

\section{Acknowledgments}

Gaëtan Podeur was the recipient of a Ph.D fellowship from the French Ministry of Higher Education and Research.

\section{References}

Alper, M.D., Ames, B.N., 1975. Positive selection of mutants with deletions of the gal-chl region of the Salmonella chromosome as a screening procedure for mutagens that cause deletions. Journal of Bacteriology 121, 259-266.

Aziz, R.K., Bartels, D., Best, A.A., DeJongh,M., Disz, T., Edwards, R.A., Formsma, K., Gerdes, S., Glass, E.M., Kubal, M., Meyer, F., Olsen, G.J., Olson, R., Osterman, A.L., Overbeek, R.A., McNeil, L.K., Paarmann, D., Paczian, T., Parrello, B., Pusch, G.D., Reich, C., Stevens, R., Vassieva, O., Vonstein, V., Wilke, A., Zagnitko, O., 2008. The RAST Server: rapid annotations using subsystems technology. BMC Genomics 9, 75. 
Bjornsdottir, K., Bolton, G.E., McClellan-Green, P.D., Jaykus, L.-A., Green, D.P., 2009. Detection of Gram-negative histamine-producing bacteria in fish: a comparative study. Journal of Food Protection 72, 1987-1991.

Bjornsdottir-Butler, K., Jones, J.L., Benner, R., Burkhardt, W., 2011a. Development of a realtime PCR assay with an internal amplification control for detection of Gram-negative histamine-producing bacteria in fish. Food Microbiology 28, 356-363.

Bjornsdottir-Butler, K., Jones, J.L., Benner, R.A., Burkhardt, W., 2011b. Quantification of total and specific gram-negative histamine-producing bacteria species in fish using an MPN real-time PCR method. Food Microbiology 28, 1284-1292.

CDC, 2011. Outbreak Surveillance Data. http://wwwn.cdc.gov/foodborneoutbreaks/

Chern, E.C., Siefring, S., Paar, J., Doolittle, M., Haugland, R.A., 2011. Comparison of quantitative PCR assays for Escherichia coli targeting ribosomal RNA and single copy genes. Letters in Applied Microbiology 52, 298-306.

Dalgaard, P., Mejlholm, O., Huss, H.H., 1996. Conductance method for quantitative determination of Photobacterium phosphoreum in fish products. Journal of Applied Bacteriology, 81, 57-64.

Dalgaard, P., Mejlholm, O., Christiansen, T.J., Huss, H.H., 1997. Importance of Photobacterium phosphoreum in relation to spoilage of MAP fish products. Letters in Applied Microbiology 24, 373-378.

Dalgaard, P., Madsen, H.L., Samieian, N., Emborg, J., 2006. Biogenic amine formation and microbial spoilage in chilled garfish (Belone belone belone) - effect of modified atmosphere packaging and previous frozen storage. Journal of Applied Microbiology 101, 80-95.

Dalgaard, P., Emborg, J., Kjølby, A., Sørensen, N.D., Ballin, N.Z., 2008. Histamine and biogenic amines - formation and importance in seafood. In: Børresen, T. (Ed.). 
Improving seafood products for the consumer. Woodhead Publishing Ltd., Cambridge, England, pp. 292-324.

Emborg, J., Dalgaard, P., Ahrens, P., 2006. Morganella psychrotolerans sp. nov., a histamineproducing bacterium isolated from various seafoods. International Journal of Systematic and Evolutionnary Microbiology 56, 2473-2479.

Emborg, J., Laursen, B.G., Dalgaard, P., 2005. Significant histamine formation in tuna (Thunnus albacares) at $2^{\circ} \mathrm{C}$ - effect of vacuum- and modified atmosphere-packaging on psychrotolerant bacteria. International Journal of Food Microbiology 101, 263279.

Emborg, J., Dalgaard, P., 2008. Growth, inactivation and histamine formation of Morganella psychrotolerans and Morganella morganii-development and evaluation of predictive models. International Journal of Food Microbiology 128, 234-243.

Ferrario, C., Pegollo, C., Ricci, G., Borgo, F., Fortina, M.G., 2012a. PCR Detection and identification of histamine-forming bacteria in filleted tuna fish samples. Journal of Food Science 77, M115-M120.

Ferrario, C., Ricci, G., Borgo, F., Fortina, M.G., 2012b. Species-specific DNA probe and development of a quantitative PCR assay for the detection of Morganella morganii. Letters in Applied Microbiology 54, 292-298.

Filloux, A., Hachani, A., Bleves, S., 2008. The bacterial type VI secretion machine: yet another player for protein transport across membranes. Microbiology 154, 1570-1583.

Helwigh, B., Korsgaard, H., Gronlund, A.J., Sorensen, A.H., Nygaard Jensen, A., Boel, J., BorckHog, B., 2012. Microbiological contaminants in food in the European Union in 2004-2009.Technical University of Denmark. http://www.efsa.europa.eu/en/supporting/doc/249e.pdf

Hungerford, J.M., 2010. Scombroid poisoning: A review. Toxicon 56, 231-243. 
InVS (Institut de Veille Sanitaire), 2011. Surveillance des toxi-infections alimentaires collectives. Données de la déclaration obligatoire 2011.

http://www.invs.sante.fr/Dossiers-thematiques/Maladies-infectieuses/Maladies-adeclaration-obligatoire/Toxi-infections-alimentaires-collectives/Donneesepidemiologiques. Accessed on 19/02/ 2015.

Kanki, M., Yoda, T., Ishibashi, M., Tsukamoto, T., 2004. Photobacterium phosphoreum caused a histamine fish poisoning incident. International Journal of Food Microbiology 92, 79-87.

Kim, S.H., Price, R.J., Morrissey, M.T., Field, K.G., Wei, C.I., An, H., 2002. Histamine production by Morganella morganii in mackerel, albacore, mahi-mahi, and salmon at various storage temperatures. Journal of Food Science 67, 1522-1528.

Klausen, N.K., Huss, H.H., 1987. Growth and histamine production by Morganella morganii in various temperature conditions. International Journal of Food Microbiology 5, 147156.

Macé, S, Cornet, J, Chevalier, F, Cardinal, M, Pilet, M-F, Dousset, X, Joffraud, J-J., 2012. Characterisation of the spoilage microbiota in raw salmon (Salmo salar) steaks stored under vacuum or modified atmosphere packaging combining conventional methods and PCR-TTGE. Food Microbiology. 30, $164-172$.

Macé, S., Mamlouk, K., Chipchakova, S., Prévost, H., Joffraud, J.-J., Dalgaard, P., Pilet, M.F., Dousset, X., 2013. Development of a rapid real-Time PCR method as a tool to quantify viable Photobacterium phosphoreum in salmon (Salmo salar) steaks. Applied and Environnemental Microbiology 79, 2612-2619.

Mamlouk, K., Macé, S., Guilbaud, M., Jaffrès, E., Ferchichi, M., Prévost, H., Pilet, M.-F., Dousset, X., 2012. Quantification of viable Brochothrix thermosphacta in cooked shrimp and salmon by real-time PCR. Food Microbiology 30, 173-179. 
Mavromatis, P., Quantick, P.C., 2002. Modification of Niven's medium for the enumeration of histamine-forming bacteria and discussion of the parameters associated with its use. Journal of Food Protection 65, 546-551.

McGuinness, S., McCabe, E., O’Regan, E., Dolan, A., Duffy, G., Burgess, C., Fanning, S., Barry, T., O’Grady, J., 2009. Development and validation of a rapid real-time PCR based method for the specific detection of Salmonella on fresh meat. Meat Science 83, $555-562$.

Meyer, M., Briggs, A.W., Maricic, T., Höber, B., Höffner, B., Krause, J., Weihmann, A., Pääbo, S., Hofreiter, M., 2008. From micrograms to picograms: quantitative PCR reduces the material demands of high-throughput sequencing. Nucleic Acids Research 36 , e5.

Murakami, T., 2012. Filter-based pathogen enrichment technology for detection of multiple viable foodborne pathogens in 1 day. Journal of Food Protection 75, 1603-1610.

NMKL, 2006. Aerobic count and specific spoilage organisms in fish and fish products. Nordic Committee on Food Analysis, NMKL 184.

O’Grady, J., Sedano-Balbás, S., Maher, M., Smith, T., Barry, T., 2008. Rapid real-time PCR detection of Listeria monocytogenes in enriched food samples based on the ssrA gene, a novel diagnostic target. Food Microbiology 25, 75-84.

O’Grady, J., Ruttledge, M., Sedanobalbas, S., Smith, T., Barry, T., Maher, M., 2009. Rapid detection of Listeria monocytogenes in food using culture enrichment combined with real-time PCR. Food Microbiology 26, 4-7.

Postollec, F., Falentin, H., Pavan, S., Combrisson, J., Sohier, D., 2011. Recent advances in quantitative PCR (qPCR) applications in food microbiology. Food Microbiology 28, $848-861$. 
Prester, L., 2011. Biogenic amines in fish, fish products and shellfish: a review. Food additives \& contaminants: Part A 28, 1547-1560.

Takahashi, H., Kimura, B., Yoshikawa, M., Fujii, T., 2003. Cloning and sequencing of the histidine decarboxylase genes of gram-negative, histamine-producing bacteria and their application in detection and identification of these organisms in fish. Applied and Environmental Microbiology 69, 2568-2579.

Tao, Z., Sato, M., Abe, N., Yamaguchi, T., Nakano, T., 2009. Simple and rapid detection of histamine-forming bacteria by differential agar medium. Food Control 20, 903-906.

Taskin, B., Gozen, A.G., Duran, M., 2011. Selective quantification of viable Escherichia coli bacteria in biosolids by quantitative PCR with propidium monoazide modification. Applied and Environmental Microbiology 77, 4329-4335.

Torido, Y., Ohshima, C., Takahashi, H., Miya, S., Iwakawa, A., Kuda, T., Kimura, B., 2014. Distribution of psychrotolerant and mesophilic histamine-producing bacteria in retail fish in Japan. Food Control 46, 328-342.

Untergasser, A., Nijveen, H., Rao, X., Bisseling, T., Geurts, R., Leunissen, J.A.M., 2007. Primer3Plus, an enhanced web interface to Primer3. Nucleic Acids Research 2007 35, W71-W74.

Van Spreekens, K.J.A., 1974. The suitability of a modification of long and hammer's medium for the enumeration of more fastidious bacteria from fresh fishery products. Archiv für Lebensmittel hygiene 10, 213-219.

Veciana-Nogués, M.T., Bover-Cid, S., Mariné-Font, A., Vidal-Carou, M.C., 2004. Biogenic amine production by Morganella morganii and Klebsiella oxytoca in tuna. European Food Research and Technology 218, 284-288. 
Figure 1: Standard curve showing the relationship between $C_{T}$ values and $\log$ CFU/g for serially diluted culture of $M$. morganii (A) and M. psychrotolerans (B) inoculated on canned tuna.

Figure 2: Growth of M. morganii (A) and M. psychrotolerans (B) respectively at $37^{\circ} \mathrm{C}$ and $10^{\circ} \mathrm{C}$ in MoE medium followed by plate count on TSA agar as a function of the time. The line represents a fitted exponential growth model.

Figure 3: Standard curve showing the liner relationship between $C_{T}$ values and bacterial enumeration $(\log \mathrm{CFU} / \mathrm{ml})$ of serially diluted M. morganii (A) and M. psychrotolerans (B) in MoE medium. 
Figure 1

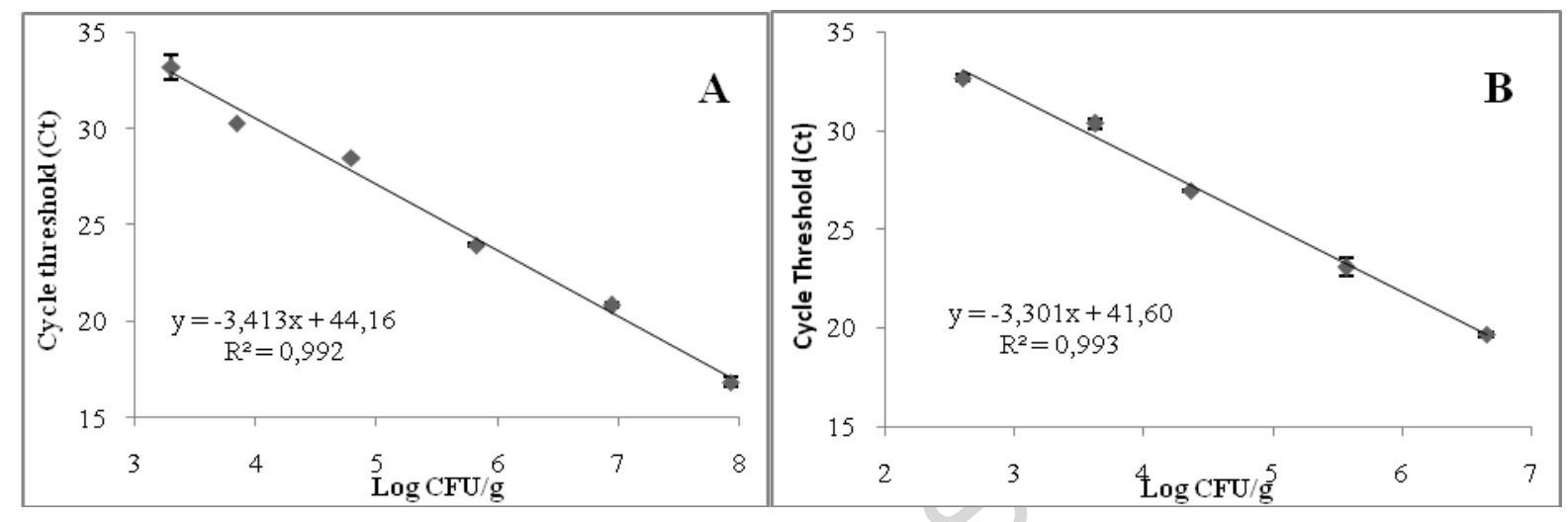


Figure 2

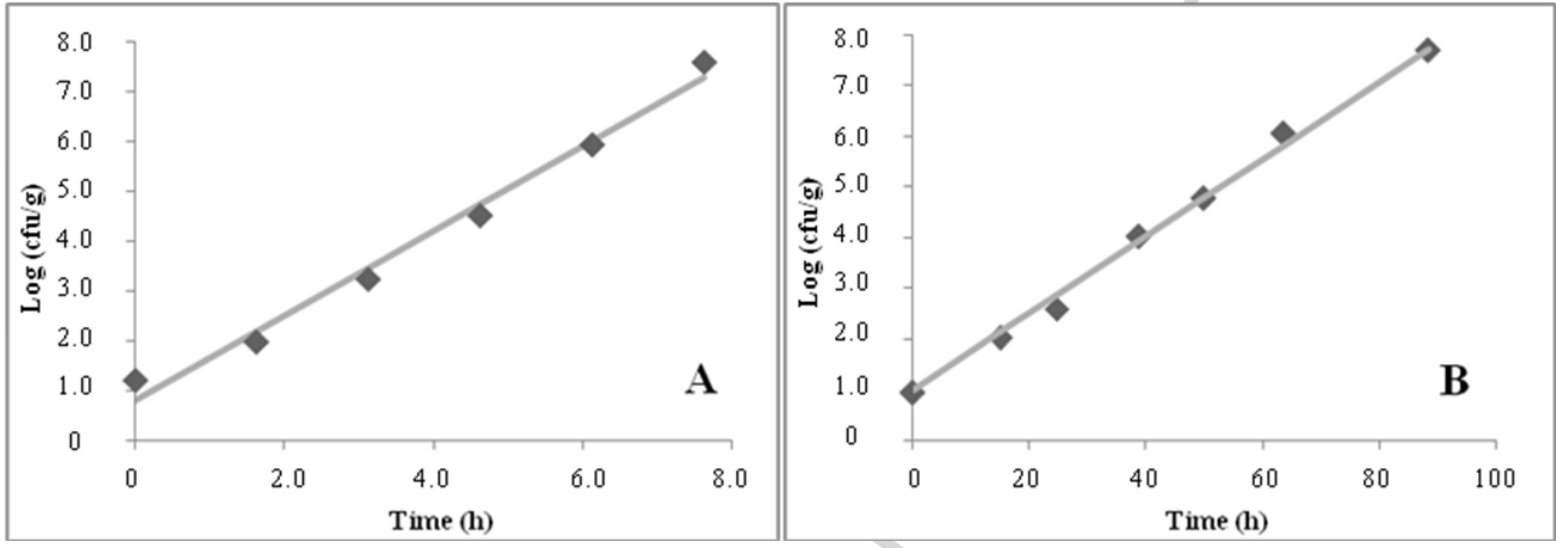


Figure 3

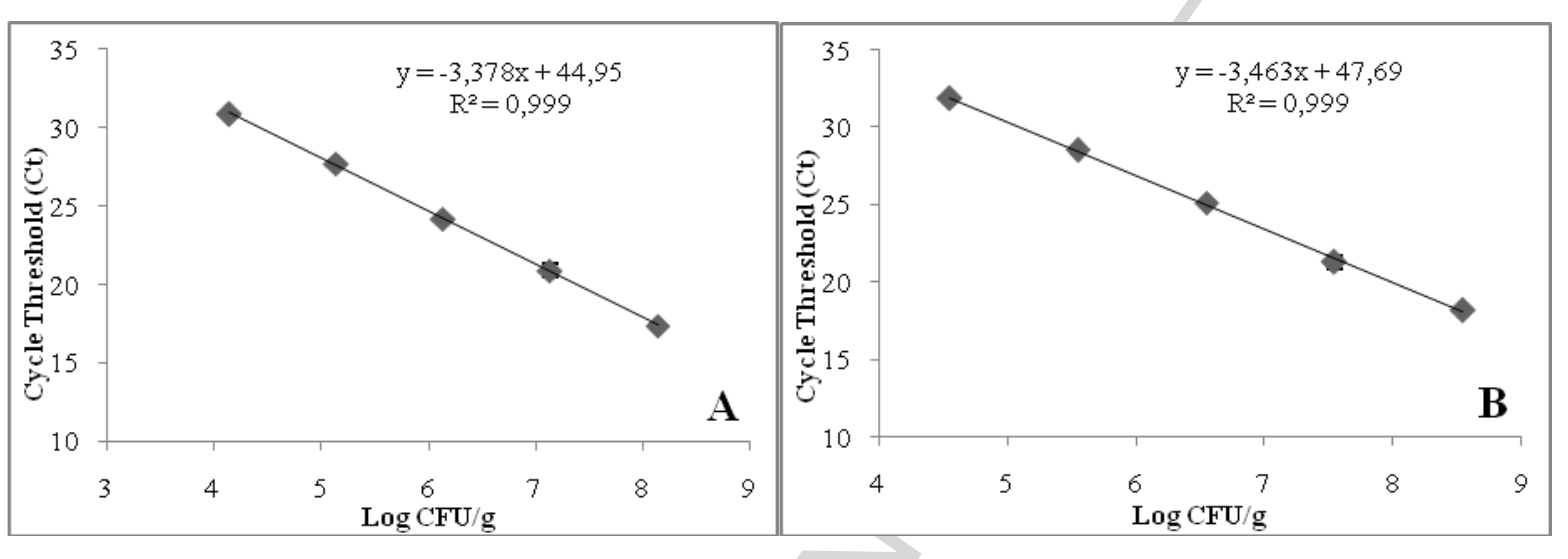


Table 1

Morganella strains and non-Morganella species used in this study.

\begin{tabular}{|c|c|c|c|c|}
\hline Bacteria & Strains & $\begin{array}{l}\text { Histamine } \\
\text { production }\end{array}$ & Collection & Origin \\
\hline Morganella psychrotolerans & $\begin{array}{l}\mathrm{U} 2 / 3^{\mathrm{T}}(\mathrm{CIP} \\
\left.109403^{\mathrm{T}}\right) \\
\mathrm{U} 2 / 4 \\
\mathrm{U} 2 / 5 \\
\mathrm{U} 2 / 6 \\
\mathrm{U} 2 / 7 \\
\text { FD24 } \\
\text { 1F10 } \\
\text { 2F6 } \\
\text { JB-T11 } \\
\text { JB-T12 } \\
\text { JB-T16 } \\
\text { F39-1 } \\
\text { F39-3 }\end{array}$ & $\operatorname{High}^{\mathrm{a}}$ & $\begin{array}{c}\text { DTU Food and } \\
\text { CIP } \\
\text { DTU Food } \\
\text { DTU Food } \\
\text { DTU Food } \\
\text { DTU Food } \\
\text { DTU Food } \\
\text { DTU Food } \\
\text { DTU Food } \\
\text { DTU Food } \\
\text { DTU Food } \\
\text { DTU Food } \\
\text { DTU Food } \\
\text { DTU Food }\end{array}$ & $\begin{array}{l}\text { Cold-smoked tuna } \\
\text { Cold-smoked tuna } \\
\text { Cold-smoked tuna } \\
\text { Cold-smoked tuna } \\
\text { Cold-smoked tuna } \\
\text { Fresh Vacuum-packed tuna } \\
\text { Garfish } \\
\text { Garfish } \\
\text { Fresh Vacuum-packed tuna } \\
\text { Fresh Vacuum-packed tuna } \\
\text { Fresh Vacuum-packed tuna } \\
\text { Lumpfish roe } \\
\text { Lumpfish roe }\end{array}$ \\
\hline Morganella morganii & $\begin{array}{l}\text { LMG7874 }^{\mathrm{T}} \\
\text { DSM14850 } \\
\text { 25a32 } \\
\text { M04090 } \\
\text { U6/1 } \\
\text { NCIMB865 } \\
\text { AP28 } \\
\text { 03A11 } \\
\text { 03B10 } \\
\text { HB2810 } \\
\text { HB2811 }\end{array}$ & $\operatorname{High}^{\mathrm{a}}$ & $\begin{array}{c}\text { BCCM/LMG } \\
\text { DSMZ }^{3} \\
\text { DTU Food }^{\mathrm{b}} \\
\text { DTU Food }^{\mathrm{b}} \\
\text { DTU Food }^{2} \\
\text { NCIMB }^{4} \\
\text { DTU Food } \\
\text { DTU Food }^{\mathrm{b}} \\
\text { DTU Food } \\
\text { Ifremer } \\
\text { Ifremer }^{\mathrm{b}}\end{array}$ & $\begin{array}{l}\text { Human stool } \\
\text { Human sputum } \\
\text { Tuna } \\
\text { Clinical isolate } \\
\text { Tuna } \\
\text { Spoiled fish } \\
\text { Yellowtail } \\
\text { Smoked fish } \\
\text { Smoked fish } \\
\text { Sardine } \\
\text { Sardine }\end{array}$ \\
\hline Hafnia alvei & $\begin{array}{l}\text { DSM30163 } \\
\text { MIP2438 } \\
\text { MIP2439 } \\
\text { MIP2461 } \\
\text { MIP2467 } \\
\text { MIP2468 } \\
\text { MIP2613 } \\
\text { MIP2625 }\end{array}$ & High $^{\mathrm{a}}$ & $\begin{array}{l}\quad \mathrm{DSMZ}^{3} \\
\text { Ifremer/Oniris } \\
\text { Ifremer/Oniris } \\
\text { Ifremer/Oniris } \\
\text { Ifremer/Oniris } \\
\text { Ifremer/Oniris } \\
\text { Ifremer/Oniris } \\
\text { Ifremer/Oniris }\end{array}$ & $\begin{array}{l}\mathrm{NC}^{\mathrm{b}} \\
\text { Spoiled fresh salmon } \\
\text { Spoiled fresh salmon } \\
\text { Spoiled fresh salmon } \\
\text { Spoiled fresh salmon } \\
\text { Spoiled fresh salmon } \\
\text { Spoiled fresh salmon } \\
\text { Spoiled fresh salmon }\end{array}$ \\
\hline Raoultella planticola & DSM3069 & $\operatorname{High}^{\mathrm{a}}$ & $\mathrm{DSMZ}^{3}$ & Radish root \\
\hline Photobacterium phosphoreum & $\begin{array}{l}\text { CCUG16288 } \\
\text { 1D5 } \\
\text { FR7 } \\
\text { EBP3067 } \\
\text { EBP3079 } \\
\text { MIP2560 } \\
\text { MIP2562 } \\
\text { MIP2588 } \\
\text { MIP2591 } \\
\text { MIP2613 }\end{array}$ & $\operatorname{High}^{\mathrm{a}}$ & $\begin{array}{c}\text { CCUG }^{5} \\
\text { DTU Food } \\
\text { DTU Food } \\
\text { Ifremer/Oniris } \\
\text { Ifremer/Oniris } \\
\text { Ifremer/Oniris } \\
\text { Ifremer/Oniris } \\
\text { Ifremer/Oniris } \\
\text { Ifremer/Oniris } \\
\text { Ifremer/Oniris }\end{array}$ & $\begin{array}{l}\text { Etelismarshi } \\
\text { Garfish } \\
\text { Fresh Vacuum-packed cod } \\
\text { Salmon } \\
\text { Salmon } \\
\text { Salmon } \\
\text { Spoiled fresh salmon } \\
\text { Spoiled fresh salmon } \\
\text { Spoiled fresh salmon } \\
\text { Spoiled fresh salmon }\end{array}$ \\
\hline Photobacterium damselae & CIP102761 ${ }^{\mathrm{T}}$ & $\operatorname{High}^{\mathrm{a}}$ & $\mathrm{CIP}^{1}$ & Damselfish \\
\hline Enterobacter aerogenes & $\begin{array}{l}\text { LMG2094 }^{\text {T }} \\
\text { SF1469 } \\
\text { SF1470 }\end{array}$ & $\operatorname{High}^{\mathrm{a}}$ & $\begin{array}{c}\mathrm{BCCM} / \mathrm{LMG}^{2} \\
\text { Ifremer } \\
\text { Ifremer }\end{array}$ & $\begin{array}{l}\text { Sputum } \\
\text { Smoked salmon } \\
\text { Smoked salmon }\end{array}$ \\
\hline Klebsiella oxytoca & $\mathrm{LMG} 3055^{\mathrm{T}}$ & $\operatorname{High}^{\mathrm{a}}$ & $\mathrm{BCCM} / \mathrm{LMG}^{2}$ & $\mathrm{NC}^{\mathrm{b}}$ \\
\hline Enterococcus faecalis & CIP105042 & Low $^{a}$ & $\mathrm{CIP}^{1}$ & Poultry \\
\hline Pseudomonas spp. & HB2843 & Low $^{\mathrm{a}}$ & Ifremer & Tuna \\
\hline Raoultella ornithinolytica & CIP103364 ${ }^{\mathrm{T}}$ & $\operatorname{High}^{\mathrm{a}}$ & $\mathrm{CIP}^{1}$ & Human urine \\
\hline Serratia liquefaciens & SF1465 & Low $^{a}$ & Ifremer & Smoked salmon \\
\hline Staphylococcus xylosus & DSMZ20029 & Low $^{a}$ & $\mathrm{DSMZ}^{3}$ & Fermented meat product \\
\hline
\end{tabular}




\begin{tabular}{|c|c|c|c|c|}
\hline Listeria monocytogenes & RF190 & Low $^{\mathrm{a}}$ & Ifremer & Shrimp \\
\hline Shewanella putrefaciens & $\begin{array}{l}\text { CIP6929 } \\
\text { RF47 } \\
\text { RF49 }\end{array}$ & Low $^{\mathrm{a}}$ & $\begin{array}{c}\text { CIP }^{1} \\
\text { Ifremer } \\
\text { Ifremer }\end{array}$ & $\begin{array}{l}\mathrm{NC}^{\mathrm{b}} \\
\text { Vacuum-packed trout } \\
\text { Cod fillets }\end{array}$ \\
\hline Psychrobacter spp. & $\begin{array}{l}\text { CCUG } 42949 \\
\text { EBP3029 }\end{array}$ & Low $^{a}$ & $\begin{array}{l}\mathrm{CCUG}^{5} \\
\text { Ifremer }\end{array}$ & $\begin{array}{l}\text { Desalted cod } \\
\text { Salmon }\end{array}$ \\
\hline Psychrobacter aquaticus & MIP2412 & Low $^{a}$ & Ifremer/Oniris & Spoiled fresh salmon \\
\hline Acinetobacter spp. & EBP3044 & Low $^{\mathrm{a}}$ & Ifremer/Oniris & Salmon \\
\hline Vibrio cholerae & RF184 & Low $^{\mathrm{a}}$ & Ifremer & Cooked shrimp \\
\hline Carnobacterium maltaromaticum & V1 & Low $^{\mathrm{a}}$ & Ifremer/Oniris & Fish \\
\hline Vibrio parahemolyticus & RF179 & Low $^{a}$ & Ifremer & Water \\
\hline Enterococcus faecium & CIP 54.33 & Low $^{\mathrm{a}}$ & $\mathrm{CIP}^{1}$ & Canned fish \\
\hline Brochotrix thermosphacta & EBP3084 & Low $^{\mathrm{a}}$ & fremer/Oniris & Salmon \\
\hline Carnobacterium jeotgali & KCTC 13251 & Low $^{\mathrm{a}}$ & $\mathrm{KCTC}^{6}$ & Shrimp \\
\hline Leuconostoc gelidum & LHIS2959 & Low $^{a}$ & Ifremer/Oniris & Mackerel fillets \\
\hline Carnobacterium divergens & V41 & Low $^{a}$ & Ifremer/Oniris & Fish viscera \\
\hline Escherichia coli & CIP 76.24 & Low $^{\mathrm{a}}$ & $\mathrm{CIP}^{1}$ & $\mathrm{NC}^{\mathrm{b}}$ \\
\hline Lactobacillus curvatus & LHIS2886 & Low $^{a}$ & Ifremer/Oniris & Fresh sardine \\
\hline Lactobacillus fuchuensis & LHIS2997 & Low $^{a}$ & Ifremer/Oniris & Fresh mackerel \\
\hline Lactobacillus sakei & LHIS2855 & Low $^{a}$ & Ifremer/Oniris & Fresh sardine \\
\hline
\end{tabular}

${ }^{a}$ High: Production of histamine between $200-5000 \mathrm{mg} / \mathrm{l}$ in histidine broth. Low: 0 to $200 \mathrm{mg} / \mathrm{l}$ of histamine in histidine. broth.

${ }^{\mathrm{b}}$ See Emborg et al. (2006) for the origin and isolation of these isolates. NC: Not communicated

${ }^{1}$ CIP : Collection de l'Institut Pasteur ; ${ }^{2}$ BCCM/LGM : Belgian Coordinated Collections of Microorganisms, ${ }^{3}$ DSMZ :

Deutsche Sammlung von Mikroorganismen und Zellkulturen; ${ }^{4}$ NCIMB : National Collections of Industrial, Marine and Food

Bacteria, ${ }^{5}$ CCUG : Culture Collection, University of Göteborg, Sweden, ${ }^{6}$ KCTC : Korean Collection for Type Cultures. 
Table 2

Antibiotics tested for inhibition of non-Morganella species in the enrichment procedure.

\begin{tabular}{|c|c|c|c|c|c|c|c|c|c|}
\hline Antibiotics & $\begin{array}{l}\text { Concentration tested } \\
(\mathrm{mg} / \mathrm{l})\end{array}$ & $\begin{array}{c}\text { M. psychrotolerans } \\
\text { U2/3' }, \text { JB-T11, F39-1 }\end{array}$ & LMG7874 $^{\text {T }}$ & $\begin{array}{l}\text { morganii } \\
\text { DSM14850 }^{T}\end{array}$ & 03A11 & $\begin{array}{c}\text { R. planticola } \\
\text { DSM3069 }^{\mathrm{T}}\end{array}$ & $\begin{array}{l}\text { E. aerogenes } \\
\text { LMG2094 }^{\mathrm{T}}\end{array}$ & $\begin{array}{c}\text { K. oxytoca } \\
\text { LMG3055 }^{\mathrm{T}}\end{array}$ & $\begin{array}{c}\text { H. alvei } \\
\text { DSM30163 }^{\mathrm{T}}\end{array}$ \\
\hline Colistin & $4 / 8 / 16 / 32$ & $+^{\mathrm{a}}$ & + & + & + & $-(4)^{\mathrm{a}}$ & $-(4)$ & $-(4)$ & $-(4)$ \\
\hline Ampicillin & $1 / 2 / 4 / 8$ & + & $-(8)$ & + & + & + & + & + & $-(2)$ \\
\hline $\begin{array}{l}\text { Amoxicillin- } \\
\text { clavulanat }\end{array}$ & $2 ; 1 / 4 ; 2$ / 8;4 / 16;32 & + & $-(16 ; 8)$ & + & + & $-(2 ; 1)$ & $-(4 ; 2)$ & + & $-(2 ; 1)$ \\
\hline Chloramphenicol & $1 / 2 / 4 / 8$ & $-(8)$ & $-(4)$ & + & $-(8)$ & $-(4)$ & $-(4)$ & $-(2)$ & $-(2)$ \\
\hline Gentamycin & $1 / 2 / 4 / 8$ & $-(4)$ & $-(4)$ & $-(8)$ & $-(4)$ & $-(1)$ & $-(4)$ & $-(2)$ & $-(2)$ \\
\hline Tobramycin & $1 / 2 / 4 / 8$ & $-(4)$ & $-(4)$ & $-(8)$ & $-(4)$ & $-(2)$ & $-(4)$ & $-(4)$ & $-(4)$ \\
\hline Florfenicol & $1 / 2 / 4 / 8$ & $-(8)$ & $-(1)$ & $-(4)$ & $-(8)$ & $-(4)$ & $-(8)$ & $-(1)$ & $-(1)$ \\
\hline Meropenem & $2 / 4$ & $-(2)$ & $-(2)$ & $-(2)$ & $-(2)$ & & & & \\
\hline Thrimethoprim & $2 / 4$ & $-(2)$ & $-(2)$ & $-(2)$ & $-(2)$ & & & & \\
\hline $\begin{array}{l}\text { Thrimethoprim + } \\
\text { Sulfamethoxazol }\end{array}$ & $2 / 4$ & - & $-(2)$ & $-(2)$ & $-(2)$ & & & & \\
\hline Oxytetracycline & $2 / 4$ & +F39-1 / - (2) & $-(2)$ & + & $-(2)$ & & & & \\
\hline Nalidixicacid & $2 / 4$ & + & + & + & $-(2)$ & & & & \\
\hline Polymixin B & $4 / 8$ & + & + & + & + & & & & \\
\hline Ciproflaxin & $2 / 4$ & $-(2)$ & $-(2)$ & $-(2)$ & $-(2)$ & & & & \\
\hline Norfloxacin & $2 / 4$ & $-(2)$ & $-(2)$ & $-(2)$ & + & & & & \\
\hline
\end{tabular}

${ }^{\mathrm{a}}+$ : Growth observed for all the tested concentrations of antibiotics; - (...): Absence of growth with a known concentration of antibiotics (mg/l). 


\section{Table 3}

Microbiological analysis on fish products after purchase or after 1 week of incubation at 2 or $10^{\circ} \mathrm{C}$

\begin{tabular}{|c|c|c|c|c|c|c|c|}
\hline Fish product & $\begin{array}{l}\text { Origin \& } \\
\text { packaging }\end{array}$ & \multicolumn{3}{|c|}{ Analysis after purchase $(\log \mathrm{CFU} / \mathrm{g})$} & \multicolumn{3}{|c|}{ Analysis after 1 week of incubation $(\log$ CFU/g) } \\
\hline Tuna Loin $\left(2^{\circ} \mathrm{C}\right)$ & $\begin{array}{l}\text { Fish market } \\
\mathrm{VP}^{\mathrm{a}}\end{array}$ & $3.49( \pm 0.52)$ & $\mathrm{ND}^{\mathrm{b}}$ & $<0,69$ & $4.37( \pm 0.50)$ & $\mathrm{ND}^{\mathrm{b}}$ & $1.68( \pm 0.48)$ \\
\hline $\begin{array}{l}\text { Frozen and thawed tuna steak } \\
\left(2^{\circ} \mathrm{C}\right)\end{array}$ & $\begin{array}{c}\text { Supermarket } \\
\mathrm{VP}^{\mathrm{a}}\end{array}$ & $3.64( \pm 0.05)$ & $\mathrm{ND}^{\mathrm{b}}$ & $<0,69$ & $2.70( \pm 0.46)$ & $\mathrm{ND}^{\mathrm{b}}$ & $1.64( \pm 0.21)$ \\
\hline Herring $\left(2^{\circ} \mathrm{C}\right)$ & $\begin{array}{l}\text { Fisherman } \\
\mathrm{VP}^{\mathrm{a}}\end{array}$ & $4.20( \pm 0.12)$ & $\mathrm{ND}^{\mathrm{b}}$ & $<0,69$ & $7.88( \pm 0.14)$ & $7.88( \pm 0.14)$ & $2.27( \pm 0.24)$ \\
\hline Matjes fillets $\left(10^{\circ} \mathrm{C}\right)$ & $\begin{array}{l}\text { Supermarket } \\
\text { MAP }^{\mathrm{c}}\end{array}$ & $1.86( \pm 0.28)$ & $\mathrm{ND}^{\mathrm{b}}$ & $<0,69$ & $2.12( \pm 1.92)$ & $\mathrm{ND}^{\mathrm{b}}$ & $2.61( \pm 0.55)$ \\
\hline Cold smoked salmon $\left(10^{\circ} \mathrm{C}\right)$ & $\begin{array}{l}\text { Supermarket } \\
\mathrm{MAP}^{\mathrm{c}}\end{array}$ & $1.23( \pm 1.07)$ & $\mathrm{ND}^{\mathrm{b}}$ & $<0,69$ & $1.70( \pm 1.70)$ & $\mathrm{ND}^{\mathrm{b}}$ & $<0,69$ \\
\hline
\end{tabular}

${ }^{\mathrm{a}} \mathrm{VP}$ : Vacuum packed

${ }^{\mathrm{b}} \mathrm{ND}$ : Not detected

${ }^{\mathrm{c}}$ MAP: Modified atmosphere packaging. 